\title{
Negative stereotypes: an analysis of social cognition in different ethnic groups. Social cognition of stereotypes
}

\section{Estereotipos negativos: un análisis de la cognición social en diferentes grupos étnicos. Cognición social de los estereotipos} \section{OPBjicogeterte}

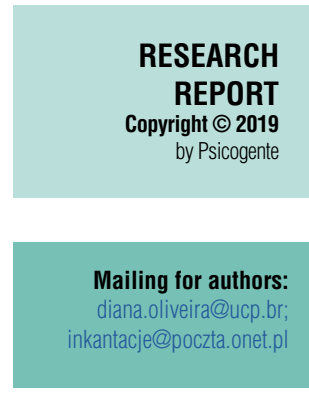

Received: $20-06-18$ Accepted: 01-04-19 Published: 01-07-19
Diana Ramos-Oliveira (iD

Catholic University of Petropolis, Rio de Janeiro, Brazil

Andrzej Pankalla ${ }^{\circledR}$

Adam Mickiewicz University, Poznan, Poland

\section{Abstract}

Introduction: The processes related to social cognitions contribute a traumatic and stressful event for some ethnic and minority groups, causing a series of psychic suffering in individuals. Social cognition considered stereotypes as characteristics of a group included in its mental representation.

Objective: This study was conducted to analyze the negative stereotypes in two cultures with different histories and geopolitical contexts, especially how these stereotypes are reflected in the cognitive component of prejudiced attitudes.

Method: Four hundred fifty-one $(N=451)$ undergraduate students volunteered to take part in the study. The participants came from careers in the area of Social Sciences and Humanities in the non-probabilistic sample. After receiving the information, they completed the Negative Stereotype Index. A descriptive analysis and the $T$-test were utilized to identify the differences between the perception and self-perception of the groups.

Results: Negative stereotype traits in Poland and Brazil found negative stereotypic traits attributed to an out-group resulted in more unfavorable evaluations than descriptions consisting of positive attributes. In both groups, generally and more importantly, their antecedents were associated with negative out-group attitudes.

Conclusion: The findings found that expectations about the out-group and negative stereotypes occur together with other negative emotions, which further intensify negative out-group attitudes. The assessment that the Poles made of the Germans was like that of the Brazilians made of the Argentines or of a group of relatively high status. That is, they considered the Germans as more arrogant, sincere, and less modest. For similar reasons, the different groups of people may dislike each other. Explanations are offered for the limitations of the study and proposal for future research.

Keywords: social cognition, negative stereotypes, ethnicity, intergroup threat, Brazil, Poland

\section{Resumen}

Introducción: Los procesos relacionados con cogniciones sociales contribuyen como evento traumatico y estresante para algunos grupos etnicos y minoritarios que causan una serie de sufrimiento psiquico en los individuos. La cognicion social considera los estereotipos como caracteristicas de un grupo incluido en su representacion mental.

Objetivo: El estudio analiza los estereotipos negativos en dos culturas con historia y contexto geopolitico diferentes, especialmente como se reflejan los estereotipos en el componente cognitivo de las actitudes prejuiciosas.

Método: Cuatrocientos cincuenta y un estudiantes de pregrado se ofrecieron como voluntarios para parti-cipar en el estudio, los participantes procedian de carreras en el area de Ciencias Sociales y Humanidades en la muestra no probabilistica. Despues de recibir la informacion, los participantes completaron el Indice de Estereotipos Negativos. Se realizo analisis descriptivo y prueba T-test de Student para conocer diferencias entre percepcion y autopercepcion de los grupos.

How to cite this article (APA):

Ramos-Oliviera, D. \& Pankalla, A. 2019. Negative stereotypes: an analysis of social cognition in different ethnic groups Social cognition of stereotypes. Psicogente English Edition 22(42), 1-15. https://doi.org/10.17081/psico.22.42.3501 
Resultados: Muestran que los rasgos estereotipados en Polonia y Brasil hallaron atributos al exogrupo que resultaron en evaluaciones mas desfavorables que en atributos positivos. En ambos grupos, sus antecedentes se asociaron con actitudes negativas para el exogrupo; sin embargo, es una cuestion mas general y mas importante.

Conclusión: Los hallazgos encontrados mostraron que las expectativas sobre el exogrupo y los estereotipos negativos ocurren en conjuncion con otras emociones negativas, que intensifican las actitudes negativas exogrupales. La valoracion que los polacos hacian de los alemanes era similar a la que hacian los brasilenos de los argentinos o de un grupo de estatus relativamente superior. Es decir, consideraban a los alemanes como mas arrogantes, sinceros y menos modestos. Los diferentes grupos pueden no gustarle el uno al otro por razones similares. Se ofrecen explicaciones para las limitaciones del estudio y para futura investigacion.

Palabras clave: cognicion social, estereotipos negativos, etnicidad, amenaza intergrupal, Brasil, Polonia.

\section{INTRODUCTION}

Fiske and Taylor (2013) identify 14 domains of social cognition, from more basic concepts such as social attention, encoding of social stimuli, and social memory representations to high-er-order social processes such as social decision-making, social inference, attitudes, stereo-typing, and prejudice.

Recently, Mathew and Raja (2018) offer us this concept in a compiled way in view of the vari-ous concepts discussed in the last century. These authors argue that social cognition refers to structures of knowledge, interpersonal processes of knowledge creation, and dissemination (i.e., encoding, storage, retrieval, and activation of social information).

In this sense, Fiske and Tablante (2015) define stereotyping as the cognitive component of bias and as category-based beliefs about a group that also involve affective-evaluative loading and behavioral tendencies. Other authors suggest that stereotypes are explicit, expressible, and by definition, social cognitions that refer to shared social knowledge in a given cultural context. The results support the notion that, in a given situation, the decision dynamics un-derlying the completion of IAT tasks adapted encompass not only the situation an individual is in and his/her learnings through socialization but also the very features of the sensorimotor apparatus (Smeding, Quinton, Lauer, Barca \& Pezzulo, 2016). These cognitive structures affect the encoding and processing of information, particularly information pertaining to out-group members (Dixon, 2000).

As such, the negative stereotypes generate a threat creating negative expectations about the conduct of out-group members. For a long time, stereotypes have been associated with the negative attitudes of an out-group (SpencerRodgers \& McGovern, 2002). Essentially, nega-tive expectations influence both information and social judgment (Hamilton, Sherman \& Ru-volo, 1990; 
Ybarra, Schaberg \& Keiper, 1999). Stephan and Stephan (1996) postulated that be-cause negative stereotypes represent negative expectations about the out-group, these ste-reotypes appear together with negative emotions (e.g., fear and anger) toward the out-group that intensify negative attitude of the out-group.

Koenig and Eagly (2005) argued that theorists describe stereotype threat as a state of self-evaluative threat, whereby anxiety about confirming a negative stereotype in others' eyes, or in one's own, produces conduct that is constant with and confirms the stereotype (Steele, Spencer \& Aronson, 2002). As explained habitually, stereotype threat is an assimila-tion to a negative group-relevant stereotype through motivational processes (Wheeler \& Petty, 2001). Theoretically, stereotype threat can happen to anyone with a group identity overladen with a negative stereotype, even if the group is historically advantaged or of high status (Steele \& Aronson, 1995).

Recent research has shown that ethno-political conflict impacts thousands of youth worldwide and has been associated with several negative psychological outcomes. For instance, analyzing results of ethnic variation in the development of negative stereotypes about ethnic outgroups among Palestinian, Israeli Jewish, and Israeli Arab indicates important ethnic differences in trajectories of negative stereotypes about ethnic outgroups, as well as variation in how such trajectories are shaped by prolonged ethno-political conflict (Niwa et al., 2014).

Also, negative stereotypes are positively related to the other threats specified by the Inte-grated Threat Theory. Besides, similar to the findings of Stephan et al. (2002), negative stere-otypes are shown to have both direct and indirect relationships with out-group attitudes. Alt-hough negative stereotypes have a moderate relationship with other threat types, they also maintain a direct, unique relationship with out-group attitudes. Complicating the issue further is the possibility that negative stereotypes may also be a result of intergroup threat. Various authors (Brewer \& Alexander, 2002; Dovidio, Brigham, Johnson \& Gaertner, 1996) have sug-gested that prejudice can be the cause of negative stereotypes as well as vice versa. If this is true, then it is assumed that intergroup threats may create negative stereotypes. Obviously, the role of negative stereotypes in future theories of intergroup threat needs to be examined from multiple perspectives. 
On the other hand, recent reviews revealed that both authoritarianism and social dominance had an indirect effect on moral exclusion mediated by negative stereotypes of the target group. Moreover, this finding suggested that negative stereotypes were more important le-gitimizing factors for RWA than for SDO (Hadarics \& Kende, 2018).

In this study, we analyze negative stereotypes in two cultures with different histories, geopo-litical contexts (but to some extent similar religion context), and ethnic groups: Brazil and Po-land. Recent studies have shown that the nature and persistence of socio-cognitive aspects, such as racism, discrimination, and prejudice, and their multiple ways can negatively impact the health of ethnic-racial groups, from access policies and practices to resources, negative stereotypes, sustained by cultural racism that promotes psychological responses that are harmful to health (Ramos-Oliveira, Magnavita \& Oliveira, 2017).

Previous studies suggest, for example, that gender shapes identity processes, including the development of ethnic identities (Pahl \& Way, 2006). Because women have traditionally been the bearers of culture, ethnic minority girls may suffer more thorough enculturation into their ethnic groups' heritages, giving rise to higher levels and/or greater increases of affirmation and belonging during at any stage of life (Phinney, 1990; Rotheram-Borus, Lightfoot, Moraes, Dopkins \& LaCour, 1998). Just as experiencing overt acts of discrimination is a powerful impe-tus for exploring the meanings and consequences of one's ethnic group membership (Cross, 1991). The level of affirmation and belonging may increase in response to perceived prejudice and discrimination (Branscombe, Schmitt \& Harvey, 1999; Schmitt, Spears \& Branscombe, 2003). Similarly, the strength of the association between discrimination and ethnic identity may vary with the source of discrimination (Pahl \& Way, 2006).The goal of the present study is to provide a preliminary investigation on how stereotypes reflect in the cognitive component of prejudicial attitudes in two cultures (Brazil and Poland)

\section{METHOD}

\subsection{Design}

The study uses the cross-sectional methodology. The data collection was carried out through questionnaires. The confidentiality of participants' data was said to be fulfilled through anonymity. 


\subsection{Participants}

The participants came from careers in the area of Social Sciences and Humanities in the non-probabilistic sample. Collaboration and volunteerism were very vital factors in the whole process of the development of this study, both by the professionals involved and by the undergraduate students. The application of the questionnaire was conducted in the classroom. In the case of the University of Poland, the questionnaires were translated into the Polish language. To avoid having an overly heterogeneous sample of undergraduate students in different countries, a sample in terms of careers in the area of Social Sciences and Humanities and age was recruited.

A total of four hundred fifty-one students from Poland and Brazil participated in the study. The Brazilian sample consisted of $73.3 \%$ females and $26.7 \%$ males; Polish sample comprised of $77.2 \%$ females and $22.8 \%$ males, with ages from 22 to 25 years, 25.58 (SD = 6.83) in Brazil and 21.79 in Poland (SD = 2.92). Many of the participants from Brazil and Poland worked and studied at the same time (38\% in Brazil and $36.3 \%$ in Poland). With regard to the marital status of the sample, $79.5 \%$ of Brazilians were single, compared with $96 \%$ in Poland.

\subsection{Measure}

\subsubsection{Negative Stereotype Index (W. G. Stephan \& Stephan, 1996)}

Negative Stereotype Index was used to evaluate stereotypes as an aspect of social cognition. As regarded, negative stereotypes lead to feelings of threat, perceived realistic threats, and perceptions of value differences (Stephan et al., 2002). These stereotypes were assessed by a 12 -item scale asking participants to estimate the percentage of the out-group possessing each of 12 traits (e.g., hard-working, unintelligent, arrogant, aggressive, modest, athletic, ambi-tious, untrustworthy, insincere, materialistic, loud, and clannish) on a 10 -point scale from $1(0 \%-10 \%)$ to $10(91 \%-100 \%)$.

- Brazilian evaluated intergroups (national) African, Argentine, and Portuguese, in addition to self-assessment of the national group.

- Polish evaluated intergroups (exo) Germans, Gypsies, and Jews, in addition to self-assessment (endo) of the Poles.

Within its psychometric properties, the instrument shows a level of reliability of.77 in Brazil and.78 in Poland in Cronbach alpha. 


\subsection{Procedure}

The research protocol for this study was approved by the Institutional Review Boards of the University of Basque Country where the author was taking PhD. The choice of the groups follows pre-established criteria. For example, in Brazil and Poland, there were no foreign students allowed in classrooms. However, the work was adjusted to the possibilities of professionals in each country and their students to compose the sample. After their regular classes, participants received information about the study's purpose and were given a letter of informed consent that included issues of confidentiality and explained the objectives of the study and its implications. The confidentiality of participants' data was said to be fulfilled through anonymity.

\subsection{Data analysis}

Descriptive analyses were performed. Student's T-test was applied for independent samples in order to analyze statistically significant differences between the perception and self-perception of the Brazilian in-group toward other out-group (Africans, Argentines, and Portugueses) in relation to negative stereotypes. In addition, with the perception of other ethnic groups, for example, the Poles toward the Germans, Gypsies, and Jews were analyzed.

\subsection{Conflict of interest}

This work is original and has not been sent to another journal. The authors declare that there is no conflict of interest. All the authors have contributed equally to this study. The work complies with all the ethical and legal standards in the country of realization.

\section{RESULTS}

\subsection{Perception of Brazilians in relation to negative stereotypes in} different ethnic groups

\subsubsection{Africans}

Brazilians point out that Africans do more hard work $t(52)=-2.156, p<.03$. The average for Brazilians and Africans was 7.25 (SD = 1.89) and 7.92 (SD = $2.11)$, respectively. However, Brazilians $(M=4.71, S D=2.0)$ score higher on the aggressive stereotype $t(55)=3.74, p<.001$ than Africans $(M=3.93$, SD $=1.9)$ as well as on the ambitious stereotype $t(53)=6.06, p<.001$. Clearly, Brazilians $(M=6.13, S D=2.47)$ are more ambitious than Africans $(M=4.08$, $\mathrm{SD}=2.36$ ). Also, in traits like untrustworthy $t(54)=3.42, p<.001$, insincere 
$t(54)=3.69, p<.001$, and materialistic $t(53)=5.54, p<.001$, Brazilians obtained a higher average compared with Africans.

The means found for the following stereotypes were as follows: Untrustworthy: Brazilians $(M=4.71, S D=2.43)$, Africans $(M=3.76, S D=2.41)$; Insincere: Brazilians $(M=4.78, S D=2.40)$, Africans $(M=3.60, S D=2.50)$; and materialistic: Brazilians $(M=6.09, S D=2.53)$, Africans $(M=4.19, S D=2.57)$.

\subsubsection{Argentines}

When Brazilians were asked what negative stereotypes they would attribute to the Argentines, the former $(M=7.19, S D=1.76)$ consider that they perform more hard work $t(46)=6.20, p<.001$ than Argentines $(M=4.91$, $S D=2.53)$. But they describe Argentines $(M=6.89, S D=2.25)$ to be more arrogant $t(45)=-5.08, p<.000$ than Brazilians $(M=4.67, \mathrm{SD}=1.82)$, as they consider Argentines as more aggressive $t(47)=-3.15, p<.003$. Argentines and Brazilians have an average of $6.45(S D=2.32)$ and $5.13(S D=.14)$, respectively. Finally, Brazilians $(M=4.87, S D=2.24)$ scored to be more modest $t(44)$ $=3.25, p<.002$ than Argentines $(M=3.64, \mathrm{SD}=2.58)$.

\subsubsection{Portuguese}

In relation to the group of Portuguese, Brazilians $(M=7.18, S D=2.18)$ do more hard work $t(48)=7.51, p<.001$ than Portuguese $(M=4.95, S D=2.66)$.

Figure 1 shows the findings mentioned previously.

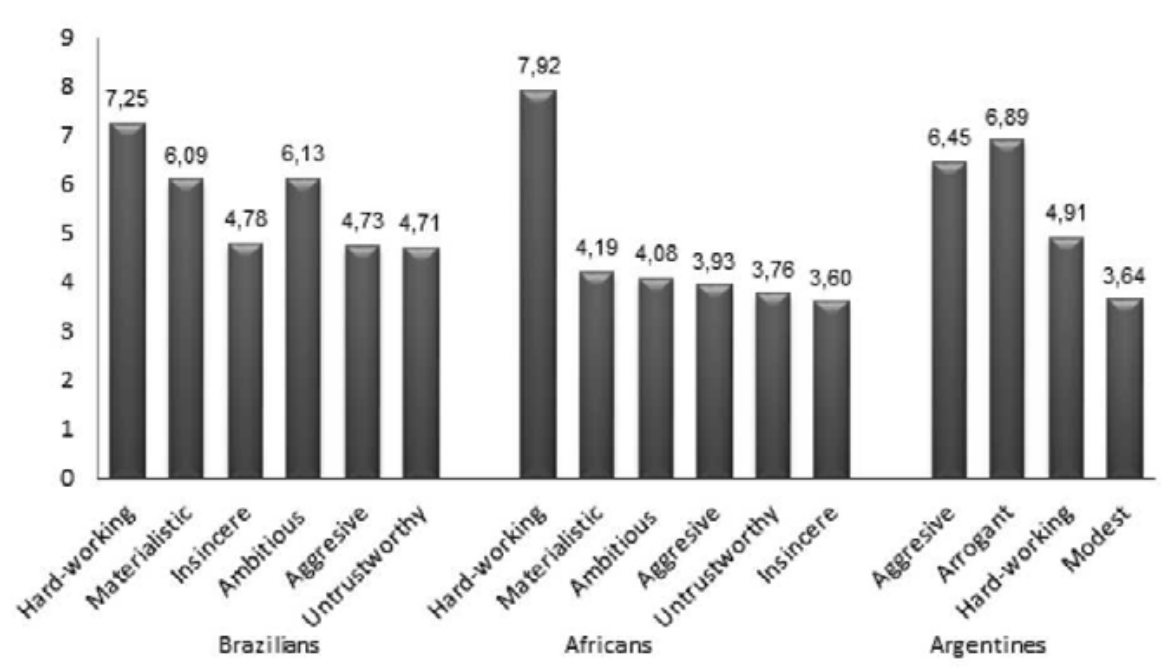

Figure 1. Brazilian's self-perception and perception in negative stereotypes of Africans and Argentines 


\subsection{Perception of Poles in relation to negative stereotypes in different} ethnic groups

\subsubsection{Germans}

When the Poles were asked about their perception of certain groups in stereotypical terms, they argued that Germans are more arrogant $t(48)=$ $-2.74, p<.009$, obtaining an average of $4.31(S D=2.03)$ for the Poles and $5.10(S D=2.32)$ for the Germans.

However, the Poles scored higher in stereotypes modest $t(48)=4.00, p<.001$ and insincere $t(48)=4.21, p<.001$ than the Germans, with means of 4.47 (SD $=1.92)$ for the in-group and $3.12(S D=1.77)$ for the out-group in stereotype modest and $4.33(S D=2.10)$ and $3.27(S D=1.61)$, respectively, in stereotype insincere.

\subsubsection{Gypsies}

Hardworking $t(44)=9.42, p<.001$ is the negative stereotype that the Poles $(M=6.84, \mathrm{SD}=1.56)$ self-attribute more than the Gypsies $(M=3.56, \mathrm{SD}=$ 1.97). On the other hand, the Poles $(M=4.43, S D=2.10)$ are considered to be more athletic $t(43)=2.86, p<.006$ than the Gypsies $(M=3.27, \mathrm{SD}=1.78)$. Furthermore, the Poles $(M=5.77, S D=1.98)$ are more ambitious $t(43)=5.35$, $p<.001$ than the Gypsies $(M=3.93, \mathrm{SD}=2.07)$. However, the Poles $(M=4.55$, $\mathrm{SD}=2.59)$ indicate that the Gypsies $(M=5.04, \mathrm{SD}=2.45)$ are clannish $t(44)=$ $-7.09, p<.000$.

\subsubsection{Jews}

As regards the negative stereotypes of out-group sample, the Poles describe the Jews as hard-working people $t(44)=-2.49, p<.01$, obtaining an average mean of 6.93 ( $S D=1.80$ ) compared with the Poles that obtained an average mean of $6.07(S D=1.90)$. Jews are more ambitious $t(42)=-3.23, p<.002$ with a mean of $6.44(S D=2.36)$ than the Poles with a mean of $5.05(S D=1.87)$. Students considered the Jews as more clannish $t(44)=-4.66, p<.001$ with a mean of 6.98 (SD = 2.31) than the Poles with an average mean of 4.98 (SD = 2.68). Relative to the group of Jews, the Poles were perceived as unintelligent $t(44)=3.67, p<.001$ with an average mean of $4.18(S D=2.24)$ compared with the Jews with an average mean of $2.91(S D=1.71)$. Moreover, the Poles are more arrogant $t(43)=2.47, p<.01$ with an average mean of 4.59 (SD = 1.92) than the Jews with an average mean of $3.70(S D=2.03)$. They are also more aggressive $t(44)=4.47, p<.001$, with $4.40(S D=1.72)$ than the Jews, 
with 3.07 (SD = 1.68). In addition, the Poles were perceived as untrustworthy $t(43)=1.99, p<.05$, that is, the Poles $(M=3.73, \mathrm{SD}=2.10)$ are considered to be more untrustworthy than the Jews $(M=3.14, \mathrm{SD}=1.86)$. Finally, they are more insincere $t(44)=3.27, p<.002$, because they scored higher in this characteristic $(M=4.98, S D=2.68)$ than the Jews $(M=3.31, S D=1.78)$.

In Poland, case groups analyzed were Poles (self-perception), Gypsies (Roms), Jews (Hebrews), and Germans. When asked about their perception of the mentioned groups in stereotypical terms, Polish students answered that Germans are the most arrogant. In terms of negative stereotypes, Polish students considered Gypsies to be the most clannish. Among the groups analyzed in Poland, Polish students have the most negative stereotypes toward Jews. For the latter, the most important traits were as follows: hard-working, ambitious, clannish, unintelligent, arrogant, aggressive, untrustworthy, and insincere (Figure 2).

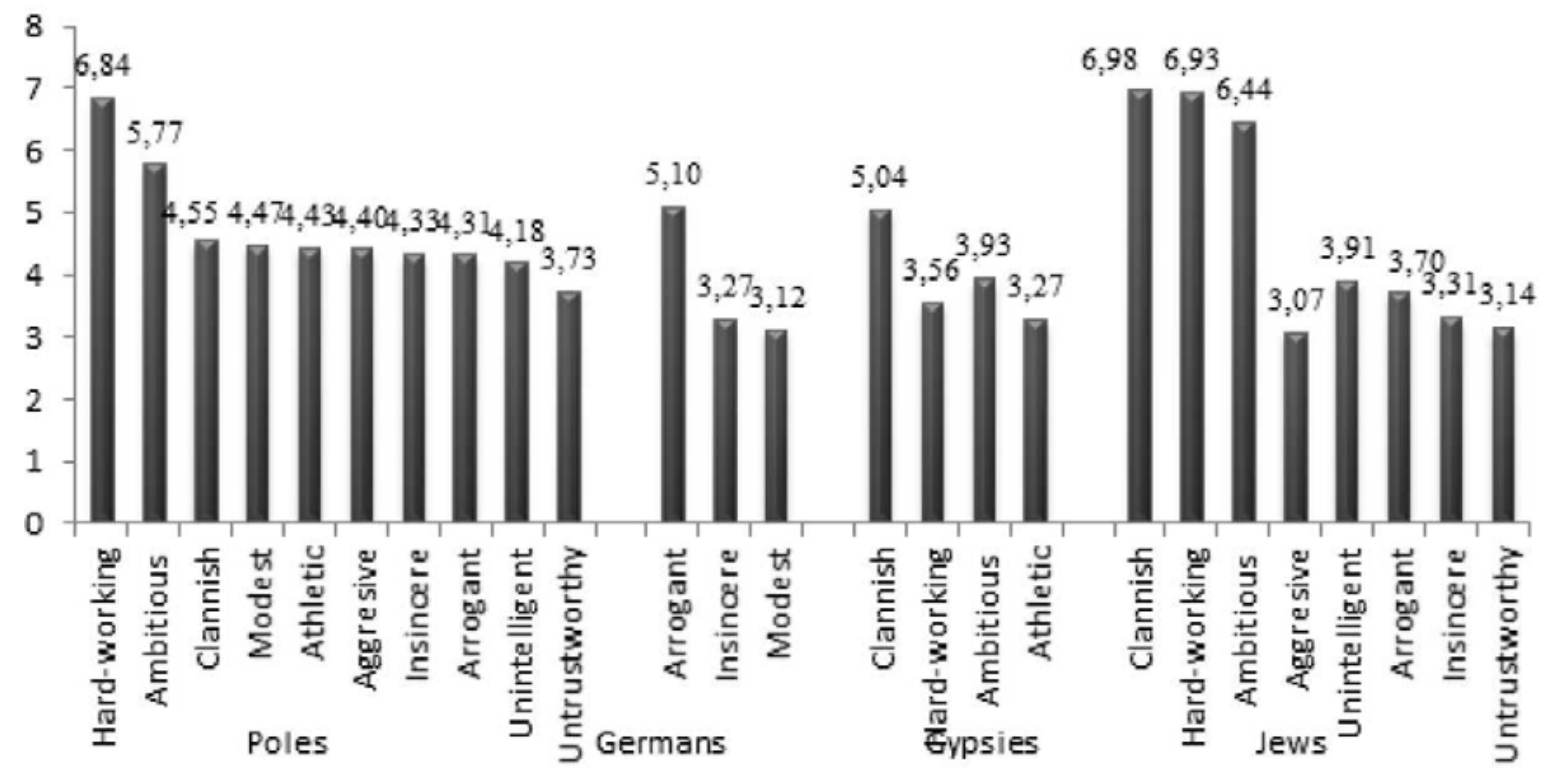

Figure 2. Polish self-perception and perception in negative stereotypes of Germans,

Gypsies, and Jews

Over the intergroup analysis performed for the $T$-test, the following results were revealed: Poles are attributed as stereotypical adjectives of the national group: hardworking, materialistic, and ambitious. To a lesser extent, the characteristics of Loud and clannish are attributed. Arrogant, aggressive, insincere, and modest were rejected as attributes of the national group. 
Likewise, the attributes of athletic, unintelligent, and untrustworthy were clearly rejected.

Of the 12 stereotypes presented, first, Brazilians describe themselves as hardworking, materialistic, Loud, and ambitious. Second, traits such as ambitious, insincere, and clannish are attributed. Third, aggressive, untrustworthy, athletic, and modest characteristics are presented. Finally, the stereotypical attributes that were attributed least are arrogant and unintelligent, which are shown in Figures 3 and 4, respectively.

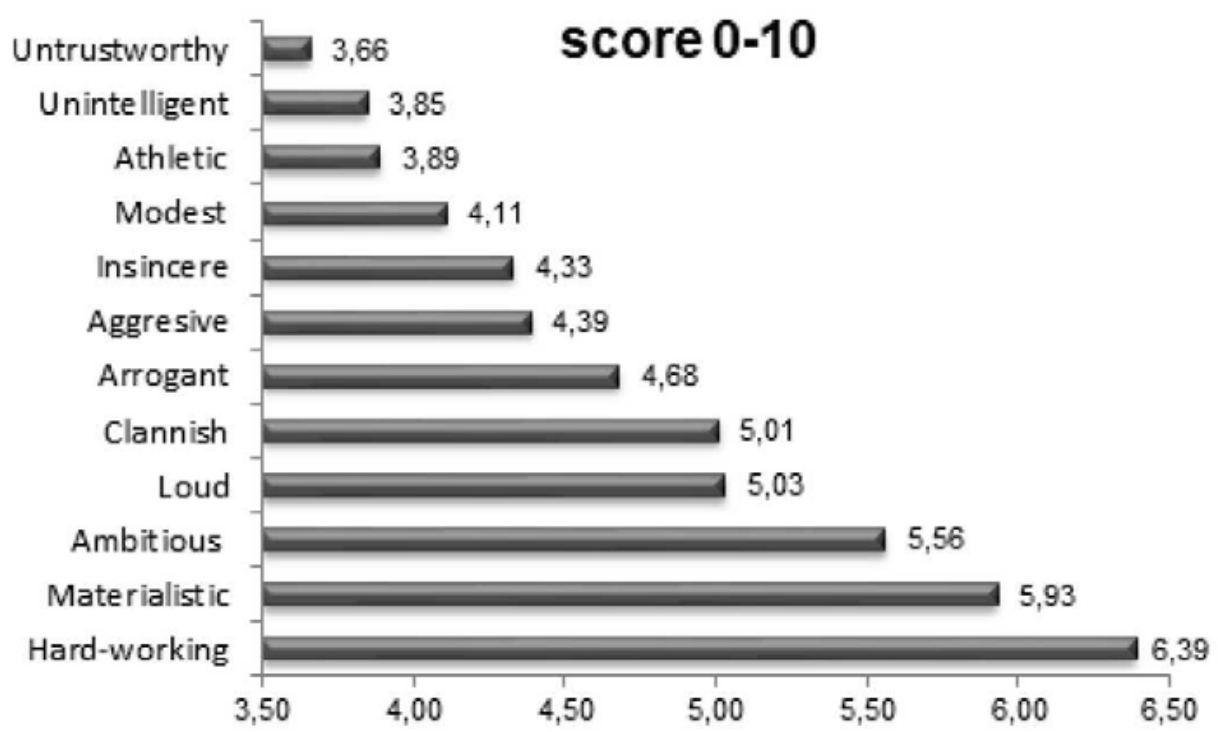

Figure 3. Polish self-perception in relation to negative stereotypes

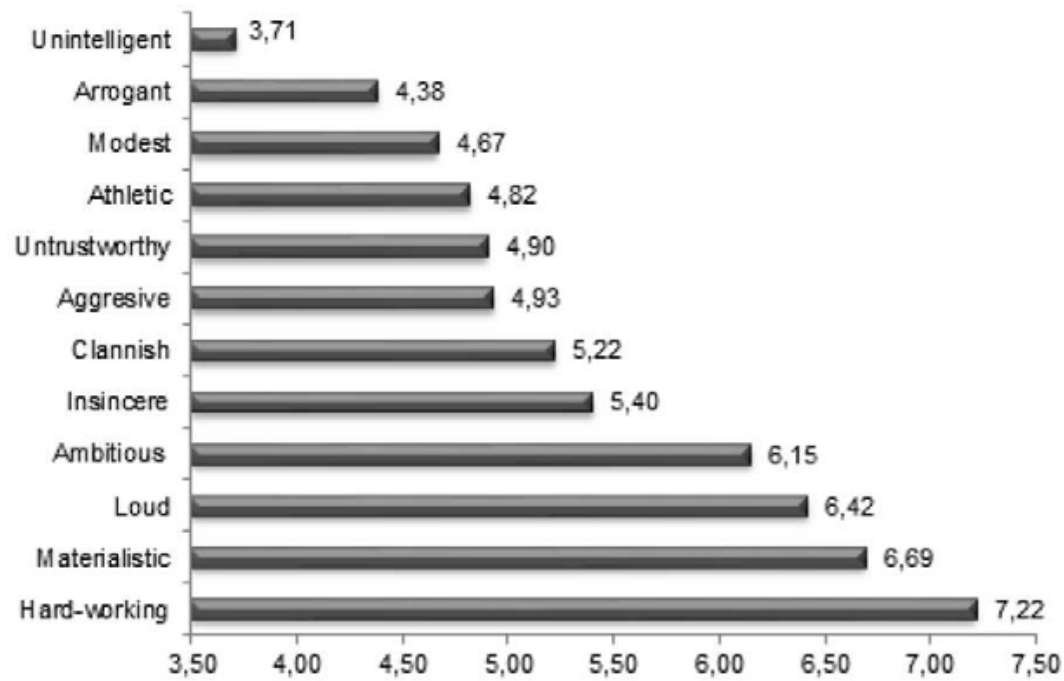

Figure 4. Brazilian self-perception in relation to negative stereotypes 


\section{DISCUSSION}

The results of this study provide further evidence about social cognition of stereotype reac-tions toward out-groups. In line with our hypothesis, negative stereotypes generated through the creation of threat negative expectations regarding the behavior of the members of the out-group.

Stereotypes have long been associated with negative attitudes toward outgroup (Riek, Mania \& Gaertner, 2006; Spencer Rodgers \& McGovern, 2002). Confirming the results with the study of Hadaricks and Kende (2018) on different ethnic groups like Muslim, Roma, and Jewish, the nexus within a motivated social cognition framework showed that negative stereotypes re-lated to the target groups are used as the justification for the motivated exclusionary practic-es. Consequently, the perception of the outgroup as violating the ingroup's norms and values authorizes people to disregard moral concerns and responsibilities toward them. The results showed further that the expectations about outgroup's negative stereotypes occur in con-junction with other negative emotions, which intensify negative outgroup attitudes.

The assessment of Argentines as little modest and aggressive reproduces a negative stereo-type about a group of equal or higher status - Argentines are perceived to do less hard work. However, compared with a group of similar status and same language, such as Portuguese, no notable differences are perceived and accepted that only Portuguese people do less hard work.

On the other hand, the Poles' valuation of the Germans was like that of the Brazilians to do Argentines, or of a group of relatively superior status. Needful to say, they considered the Germans as more arrogant, sincere, and less modest. To a group of lower status and margin-alized like the Gypsies, the Poles perceived them as doing little hard work, less ambitious, athletic, and more clannish. Finally, they perceived the Jews not only as more ambitious, doing more hard work, and more clannish but also as more intelligent, less arrogant, and less aggres-sive than the Poles. This positive stereotype of a previously persecuted group -and in a con-text of certain cultural anti-Semitism-suggests a tendency to compensate in educated envi-ronments.

The logic of clear group favoritism is relatively absent in the case of the European countries, dominating a self-critical logic and defensive acceptance of a superior group's status in the case of the Poles compared with the Germans. This study is consistent with the research in the context of teachers' bias in grading immigrants and native children in middle schools, using IAT 
technique. Teachers give lower grades to immigrant students compared with natives who have the same performance on standardized, blindly graded tests. For instance, Math teach-ers with stronger stereotypes gave lower grades to immigrants compared with natives with the same performance (Alesina, Carlana, Ferrara \& Pinotti, 2018).

In the same manner, with the classic studies presented by Fiske, Cuddy, Glick, and Xu (2002) and Cuddy and Fiske (2003), a superior and competitive group, like the Argentines and Ger-mans, is perceived to be instrumentally superior but expressively unpleasant, arrogant, and little modest. These findings corroborate with other studies that the negative stereotypical treatments attributed to an outgroup are more unfavorable evaluations than consistent de-scriptions of positive or negative attributes (Stephan, Renfro, Esses, Stephan \& Martin, 2001).

\section{CONCLUSIONS}

The negative stereotype traits in Poland and Brazil found negative stereotypic traits attributed to an out-group, resulting in more unfavorable evaluations than consistent descriptions of positive or positive and negative attributes. The foregoing stereotypic traits attributed by Bra-zilian and Polish to the other ethnic groups were more negative and rated higher. Undeniably, some of the treatments were attributed to own group members. For instance, in Poland (Figure 3), the first group was seen to be hardworking, materialistic, and ambitious, while the second group was loud, clannish, and arrogant. In addition, stereotypes that were related between them in Brazil (Figure 4) were hard-working, materialistic, loud, and ambitious, and a link was found between ambitious, insincere, and clannish.

In both groups, their antecedents were associated with negative out-group attitudes. Nota-bly, different groups of people may dislike each other for similar reasons. Many factors can increase the negative stereotypes about different target groups. For example, as demon-strated by Kim, Harwood, and Xiang (2018), their findings revealed that exposure to a threat message about immigrants (compared with a nonthreat message) resulted in more support for punitive immigration policies. The effect of negative stereotypes on intergroup bias was smaller in the nonthreat message condition than the threat message condition.

Furthermore, this study has obvious limitations, with a sample composed mainly of female and university students. Undoubtedly, more data from 
national groups on negative stereo-types must be analyzed. It is hoped that future studies will shed more light on the sources and mechanisms of social cognition of the stereotypes as a mental representation that implies the interpersonal relationship of the different ethnic groups.

ACKNOWLEDGMENT: We thank our students, research assistants, and professionals who collaborate with our study.

\section{REFERENCES}

Alesina, A., Carlana, M., Ferrara, E., \& Pinotti, P. (2018). Revealing stereotypes: Evidence from immigrants in schools. Working Paper 25333. http://www.nber. org/papers/w25333

Branscombe, N. R., Schmitt, M. T., \& Harvey, R. D. (1999). Perceiving pervasive discrimination among African Americans: Implications for group identification and well-being. Journal of Personality and Social Psychology, 77, 135-149. http:// doi.org/10.1037/0022-3514.77.1.135

Brewer, M. B., \& Alexander, M. G. (2002). Intergroup emotions and images. In D. Mackie \& E. Smith (Eds.), From prejudice to intergroup emotions: Differentiated reactions to social groups, pp. 209-225. New York: Psychology Press

Cross, J. E. Jr. (1991). Shades of black: Diversity in African-American identity. Philadelphia: Temple University Press

Cuddy, A. J. C., \& Fiske, S. T. (2003). Behavioral correlates of warmth and competence stereotypes. Poster presentado en la cuarta reunión anual de la "Society for Personality and Social Psychology,". Los Angeles

Dixon, T. L. (2000). A social cognitive approach to studying racial stereotyping in the mass media. African American Research Perspectives, 6, 60-68. https://babel. hathitrust.org/cgi/pt?id=mdp.39015042778095; view=2up;seq=66;size=150

Dovidio, J. F., Brigham, J., Johnson, B. T., \& Gaertner, S. L. (1996). Stereotyping, prejudice, and discrimination: Another look. In N. Macrae, C. Stangor, \& M. Hewstone (Eds.), Stereotypes and stereotyping, pp. 276-319. New York: Guilford

Fiske, T. S., \& Tablante, C. B. (2015). Attitudes and social cognition. In M. Mikulincer \& P. R. Shaver (Eds.) APA handbook of personality and social psychology. (Vol. 1, pp. 457-507). http://doi.org/10.1037/14341-015

Fiske, S., \& Taylor, S. E. (2013). Social Cognition: From brain to culture. 2nd ed. California: SAGE

Fiske, S. T., Cuddy, A. J. C., Glick, P., \& Xu, J. (2002). A model of (often mixed) stereotype content: Competence and warmth respectively follow from perceived status and competition. Journal of Personality and Social Psychology, 82, 878-902. http:// doi.org/10.1037/0022-3514.82.6.878

Hadarics, M., \& Kende, A. (2019). Negative stereotypes as motivated justifications for moral exclusion. The Journal of Social Psychology, 159, 257-269. https://doi. org/10.1080/00224545.2018.1456396

Hamilton, D. L., Sherman, S. J., \& Ruvolo, C. M. (1990). Stereotype-based expectancies: Effects on information processing and social behavior. Journal of Social Issues, 46, 35-60. https://doi.org/10.1111/j.1540-4560.1990.tb01922.x

Kim, C., Harwood, J., \& Xiang, J. (2018). The negative and positive influences of threat and nonthreat media messages about immigrants. International Journal of Communications, 12, 950-972. https://ijoc.org/index.php/ijoc/article/ view/7284/2278 
Koenig, A. M., \& Eagly, A. H. (2005). Stereotype Threat in Men on a Test of Social Sensitivity. Sex Roles, 52, 489-496. https://doi.org/10.1007/s11199-005-3714-x

Mathew, B., \& Raja, B. W. D. (2018). Social cognition. New Delhi: S. B. Nangia A.P.H. Publishing Corporation

Niwa, E. Y., Boxer, P., Dubow, E. F., Huesmann, L. R., Landau, S., Shikaki, K., \& Gvirsman, S. D. (2016). Negative stereotypes of ethnic out-groups: A longitudinal examination among Palestinian, Israeli Jewish, and Israeli Arab youth. Journal of Research on Adolescence, 26, 166-179. https://doi.org/10.1111/jora.12180

Pahl, K., \& Way, N. (2006). Longitudinal trajectories of ethnic identity among urban Black and Latino adolescents. Child Development, 77, 1403-1415. https://doi. https://doi.org/10.1111/j.1467-8624.2006.00943.x

Phinney, J. S. (1990). Ethnic identity in adolescents and adults: Review of research. Psychological Bulletin, 108, 499-514. https://doi.org/10.1037/00332909.108.3.499

Ramos-Oliveira, D., Magnavita, P., \& Oliveira, F. S. (2017). Aspectos sociocog-nitivos como eventos estressantes na saude mental em grupos etnicos e minoritarios no Brasil. Summa Psicologica UST, 14, 43-55. https://doi. org/10.18774/448x.2017.14.315

Riek, B. M., Mania, E. W., \& Gaertner, S. L. (2006). Intergroup threat and outgroup attitudes: A meta-analytic review. Personality and Social Psychology Review, 10, 336-353. https://doi.org/10.1207/s15327957pspr1004_4

Rotheram-Borus, M. J., Lightfoot, M., Moraes, A., Dopkins, S., \& LaCour, J. (1998). Developmental, ethnic, and gender differences in ethnic identity among adolescents. Journal of Adolescent Research, 13, 487-507. https://doi. org/10.1177/0743554898134006

Schmitt, M. T., Spears, R., \& Branscombe, N. R. (2003). Constructing a minority group identity out of shared rejection: The case of international students. European Journal of Social Psychology, 33, 1-12. https://doi.org/10.1002/ejsp.131

Smeding, A., Quinton, J. C., Lauer, K., Barca, L., \& Pezzulo, G. (2016). Tracking and simulating dynamics of implicit stereotypes: A situated social cognition perspective. Journal of Personality and Social Psychology, 111, 817-834. https:// doi.org/10.1037/pspa0000063

Spencer-Rodgers, J., \& McGovern, T. (2002). Attitudes toward the culturally different: The role of intercultural communication barriers, affective responses, consensual stereotypes, and perceived threat. International Journal of Intercultural Relations, 26, 609-631. https://doi.org/10.1016/S0147-1767(02)00038-X

Steele, C. M., \& Aronson, J. (1995). Stereotype threat and the intellectual test performance of African Americans. Journal of Personality and Social Psychology, 69, 797-811. http://doi.org/10.1037//0022-3514.69.5.797

Steele, C. M., Spencer, S. J., \& Aronson, J. (2002). Contending with group image: The psychology of stereotype and social identity threat. In M. Zanna (Ed.), Advances in experimental social psychology. (Vol. 34, pp. 379-440). New York: Academic Press

Stephan, W. G., \& Stephan, C. W. (1996). Predicting prejudice. International Journal of Intercultural Relations, 20, 409-426. http://doi.org/10.1016/0147-

(1767)(96)00026-0

Stephan, W. G., Boniecki, K. A., Ybarra, O., Bettencourt, A., Ervin, K. S., Jackson, L. A., McNatt, P. S., \& Renfro, C. L. (2002). The role of threats in the racial attitudes of Blacks and Whites. Personality and Social Psychology Bulletin, 28, 1242-1254. https://doi.org/10.1177/01461672022812009 
Stephan, W. G., Renfro, C. L., Esses, V. M., Stephan, C. W., \& Martin, T. (2001). The effect of threat on attitudes toward immigrants. Unpublished manuscript. Las Cruces, NM: New Mexico State University

Wheeler, S. C., \& Petty, R. E. (2001). The effects of stereotype activation on behavior: A review of possible mechanisms. Psychological Bulletin, 127, 797-826. http:// dx.doi.org/10.1037/0033-2909.127.6.797

Ybarra, O., Schaberg, L., \& Keiper, S. (1999). Favorable and unfavorable target expectancies and social information processing. Journal of Personality and Social Psychology, 77, 698-709. http://doi.org/10.1037/0022-3514.77.4.698

Esta obra está bajo: Creative commons attribution 4.0 international license. El beneficiario de la licencia tiene el derecho de copiar, distribuir, exhibir y representar la obra y hacer obras derivadas siempre y cuando reconozca y cite la obra de la forma especificada por el autor o el licenciante.

\section{(cc) BY}

